\title{
Euan W. MacKie, Professor Challenger and his Lost Neolithic World: The Compelling Story of Alexander Thom and British Archaeoastronomy
}

\author{
Oxford: Archaeopress, 2020. Paperback 158 pp., 81 figures ISBN \\ 9781784918330. £30.00.
}

\section{Kenneth Brophy}

University of Glasgow

Kenny.Brophy@glasgow.ac.uk

It is sad reviewing a book published so soon after the author's death (see Hunter 2020 for an obituary), as is the case with Euan MacKie's book Professor Challenger and his Lost Neolithic World. The challenge is to offer an honest and balanced view of the work whilst always being aware that the author is unable to respond. It would be fair to say that this book has a few issues which I will outline below, but if you are interested in the history of archaeology or the development of archaeoastronomy then this publication will have more than enough content to satisfy.

Ostensibly, the book is a biographical study of the archaeological career of engineering academic Alexander Thom (1894-1985), whose archaeoastronomical research has been influential but also controversial within archaeology. As such, it offers an interesting addendum to Archie Thom's biography of his father Walking in All of the Squares (1995). It is worth noting that Professor Challenger contains perhaps the clearest explanation of the main theories that Alexander Thom developed - especially around the metrology and geometry of stone circles and observations about long alignments on heavenly bodies encoded in megaliths and the landscape. However, the book also serves as something of an autobiographical account of MacKie's own innovative and distinctive archaeological approach to the subject that he was the first to name "archaeoastronomy". MacKie's narrative includes for instance a lot of detail about his own excavations and fieldwork, testing Thom's ideas about astronomical alignments and megaliths, while various arguments/debates with other archaeologists are recounted in frank detail.

The book consists of two different types of essays. Firstly, there are several chapters that focus on the development of Thom's theories and approach to archaeoastronomy, including recounting the archaeological establishment's reaction to his body of work. Key studies both pro- and con-Thom are discussed and MacKie reflects on what he perceives 
to be a softening of attitudes towards the potential of solar and lunar alignments in prehistory from an initially hostile stance taken up in the pages of journals such as Antiquity in the 1970s. This all very much benefits from an insider's perspective: Mackie was part of these arguments and took a lot of flack for his support of Thom, whom he first met in 1970 during the filming of an episode of the BBC television series Chronicle. MacKie's important and rambunctious role within these historical processes forms the basis of the second group of chapters in the book, which recount the author's famous excavations at sites such as Kintraw, Argyll and Bute, and Cultoon stone circle, Islay. This adds little new to the story, but fresh observations are offered, such as those related to a potential "long alignment" MacKie identified at Sornach coir Fhinn stone circle, North Uist, which was investigated during a short break on that island.

There are detailed descriptions of alignments identified on Orkney, from Maeshowe to the Ness of Brodgar, and also extensive discussions about Stonehenge and Knowth. It is a pity that so much of the book focuses on the well-worn "core" areas of Orkney, Wessex and the Bend of the Boyne, but as noted above there is some content on western Scotland too. The account of Stonehenge alignments and geometry, from the work of Gerald Hawkins onwards, is of especial interest (as all things Stonehenge seem to be these days). However, in the end, Mackie's narrative of the complexity of Stonehenge underpinned by "geometrical and astronomical facts" does not convince and suffers from a lack of engagement with recent excavation and fieldwork results. For instance, his historiographical account relies on a few early interim statements from the Stonehenge Riverside Project and not the much more detailed recent papers on the chronology and development of Stonehenge and surrounds (such as Darvill 2016; Willis et al. 2016). The book concludes with an appendix entitled, "Is There Plausible Evidence that the Ness of Brodgar Priesthood had any Esoteric Knowledge?". It is I hope not a spoiler to say MacKie's answer to this question is "yes", based on his own fieldwork in the past decade, and it is interesting to see such close engagement with this exciting site, which of all discoveries in the British Neolithic during MacKie's lifetime seems most likely to hint at a "priestly" temple-dwelling community.

It is incumbent upon me to note some of the book's shortcomings. In general, the editing is a bit slack and examples of repetition and contradiction are evident, probably a direct result of this being in effect a collection of papers and essays rather than a cohesive book. Several sections of the book are literally reproductions of previously published papers, notably an account of the author's work at Knowth, initially appearing in the journal Time and Mind (MacKie 2013). One chapter is little more than a series of reviews of books and journal papers on prehistoric astronomy topics since 2000. There is no doubt that the book lacks any real engagement with similarly recent research into the British Neolithic and Bronze Age. This becomes a real weakness when Mackie talks about sites such as Durrington Walls, where ironically major discoveries regarding chronology and houses actually support the arguments MacKie had been making for decades! This is a shame, as it leaves the observations made about priesthoods and megaliths bereft of any kind of social context, with almost no other aspect of Neolithic life discussed in the book, which essentially is left presenting the archaeology of an elite. There is up-to-date 
content on the Ness of Brodgar, but aside from this, precious few sources in the bibliography post-date 2010 . It seems likely that parts of the book were written quite some time ago, for instance where "recently" is 1998, and some weblinks in the text are dated. It is unfair to dwell on this to any great extent as keeping on top of the exponentially growing numbers of sources becomes much more challenging when one is retired, and Mackie also suffered from ill health in his last few years.

The product of this patchy mixture of content and quality is still, in my opinion, a richly illustrated account of an important, but much marginalised debate within archaeology and, as such, of great historiographical value. The "I was there" perspective offered by the author gives his support of Thom additional weight, but ultimately there is little new in this book and it could be argued that MacKie was far from a detached observer of the events described therein. I would also say that MacKie writes what you would expect him to, with his consistent stance on issues such as "Neolithic wise men" (it always seems to be men) and chiefdoms of a piece with earlier publications going back to the 1970s (such as MacKie 1977). It is, however, interesting to read MacKie's reflection on some of his earlier statements being problematic (such as his use of the word science to describe Neolithic ritual practices and again in the title of his 1977 book), and this approach has much to recommend it. I think we can indulge the strong pro-Thom sentiment shown across this book: the men were clearly friends and worked well together despite their different disciplinary backgrounds. I enjoyed reading this book and, approached in the right spirit and accepting of its limitations and format, you may well enjoy reading it too.

\section{References}

Darvill, T., 2016. "Houses of the Holy: Architecture and Meaning in the Structure of Stonehenge, Wiltshire, UK". Time and Mind 9 (2): 89-121. https://doi.org/10.1080/1751696X.2016.1171496

Hunter, F., 2020. "Euan W. MacKie (10 February 1936-2 November 2020)". Scottish Archaeological Journal 43 (1): 114-117. https://doi.org/10.3366/saj.2021.0160

MacKie, E. W., 1977. Science and Society in Prehistoric Britain. London: Elek.

MacKie, E. W., 2013. "A 'Rosetta Stone' for the Prehistoric Solar Calendar? Kerbstone K15 at Knowth, Ireland". Time and Mind 6 (2): 211-230. https://doi.org/10.2752/175169713X13589680081894

Thom, A. S., 1995. Walking in All of the Squares: A Biography of Alexander Thom, Engineer, Archaeoastronomer, Discoverer of a Prehistoric Calendar, the Geometry of Stone Rings, and Megalithic Measurement. Glendaruel, UK: Argyll Publishing.

Willis, C., P., J. Marshall, M. Pitts McKinley, J. Pollard, C. Richards, J. Richards, J. Thomas, T. Waldron, K. Welham and M. Parker Pearson, 2016. "The Dead of Stonehenge". Antiquity 90 (350): 337-356. https://doi. org/10.15184/aqy.2016.26 